\title{
A arte transmídia de instalação nas décadas de 1960/1970 e na contempora- neidade (André Parente e Kátia Maciel)
}

\author{
NATASHA MARZLIAK \\ JOSÉ EDUARDO RIBEIRO DE PAIVA \\ MARCELO ANTONIO MILARÉ VERONESE
}

\section{Resumo}

A arte no contexto da transmídia, ao se contaminar por recursos de diversos meios, tais como o cinema, o vídeo e as novas tecnologias audiovisuais, ultrapassa fronteiras, abre passagens e desloca espaços e temporalidades sugerindo a participação do público. A partir de uma proposição comparativa e temporal, este estudo pretende traçar possibilidades dialógicas dos conceitos e práticas da arte de instalação transmidiática de vanguarda que tiveram início na década de 1960 e se prolongaram por toda a década de 1970 - sobretudo os do grupo

Palavras-chave: Arte transmídia, instalação, audiovisual Fluxus, de Jack Smith, do Cinema expandido, das manifestações ambientais de alguns artistas brasileiros (a exemplo de Hélio Oiticica) e da atualidade, com enfoque em dois artistas brasileiros: André Parente e Kátia Maciel. 


\title{
The transmedia art installation in the decades of 1960/1970 and in the contemporaneity (André Parente and Kátia Maciel)
}

\author{
NATASHA MARZLIAK \\ JOSÉ EDUARDO RIBEIRO DE PAIVA \\ MARCELO ANTONIO MILARÉ VERONESE
}

\begin{abstract}
The art in the context of transmedia, affected by resources from various media such as film, video and new audiovisual technologies, goes beyond borders, open passages and moving spaces and temporalities suggesting public participation. From a comparative and temporal proposition, this study aims to draw dialogic possibilities of the concepts and practices of the vanguard transmedia art installation that began in the 196os and lasted throughout the 1970s especially those of the Fluxus group, Jack Smith, expanded Cinema, environmental manifestations of some Brazilian artists (like Helio Oiticica) and today, focusing on two Brazilian artists: André Parente and Kátia Maciel.
\end{abstract}

Keywords:

Transmedia art, installation, audio-visual 


\title{
El arte transmedia de instalación en las décadas de $1960 / 1970$ y en la contempo- raneidad (André Parente y Kátia Maciel)
}

\author{
NATASHA MARZLIAK \\ JOSÉ EDUARDO RIBEIRO DE PAIVA \\ MARCELO ANTONIO MILARÉ VERONESE
}

\section{Resumen}

El arte en el contexto de transmedia, al contaminarse con los recursos de diversas medias, tales como el cine, el video y las nuevas tecnologías audiovisuales, ultrapasa fronteras, abre caminos y disloca espacios y temporalidades sugiriendo la participación del público. A partir de una propuesta comparativa y temporal, este estudio pretende trazar posibilidades dialógicas de los conceptos y prácticas del arte de instalación transmediática de vanguardia que tuvo inicio en la década de 1970 - sobre todo los del grupo Fluxuz,

Palabras-clave: Arte transmedia, instalación, audiovisual de Jack Smith, del Cine expandido, de las manifestaciones ambientales de algunos artistas brasileños (por ejemplo de Hélio Oiticica) y de la actualidad, centrándose en dos artistas brasileños: André Parente y Kátia Maciel. 


\section{Introdução}

Desde que teve suas primeiras experimentações híbridas na década de 1960 e que se prolongou por toda a década de 1970, a arte contemporânea transmídia no contexto do audiovisual articula inúmeras possibilidades de sentido ao contaminar entre si os campos do cinema, do vídeo e das novas tecnologias, a fim de habitar espaços de imersão: as instalações. São criados ambientes que alteram os sentidos espaço-temporais e a narrativa linear, o que exige do espectador (agora participante) uma atitude ativa de recepção e recombinação cognitiva da "desordenação" de imagens e sons. Os espaços imersivos, ao deslocar o espaço habitual e conhecido, exigem o corpo em movimento - o corpo em meio a uma situaçãovídeo-cinema cuja mente pensante se encontra entre imagens fragmentadas, que mudam a temporalidade da obra. Esses campos transmidiáticos pluralizam os sentidos, implicando agora que cada pessoa que experimenta a obra tem seu entendimento individual dela, ou melhor, cada indivíduo se torna parte constitutiva dela.

Com o intuito de uma melhor compreensão e discernimento sobre esse fazer contemporâneo, relaciona-se aqui conceitos e práticas dos fazeres transmidiáticos de instalação das décadas de 1960 e 1970 com o que se produz hoje nesse universo, evidenciando relações e diálogos possíveis. Considerando a obra como um evento, um acontecimento de experimentações, um dispositivo e não um objeto, o que define a tendência contemporânea no discurso e modo de fazer da arte, deseja-se traçar uma sorte de cartografia de tendências dos procedimentos da pós-modernidade da arte transmídia de instalação.

Asintersecções entrearte, cinema, vídeoe meios tecnológicos na construção de instalações tiveram início a partir do final 
da década de 1960 e se desenvolveram durante toda a década de 1970. São conhecidos os exemplos das experimentações cinemáticas-ambientais do grupo Fluxus (os Fluxfilms), os eventos de Jack Smith, o Cinema Expandido e a videoarte (da videoescultura à videoinstalação). Particularmente no Brasil, é significante salientar a importância dos trabalhos de artistas como Hélio Oiticica e Wesley Duke Lee, para citar dois exemplos pioneiros no contexto nacional do período mencionado.

Depois de todas as experiências apreendidas em quatro décadas, as quais mediaram os cruzamentos de diversos meios e linguagens, o modo de fazer da arte transmídia perpassa, entre outros, pela radicalização da importância da vida individual inserida num espaço-tempo de coletividade, em detrimento da contemplação de uma imagem, dialogando com o conceito de participação iniciado pelos artistas de vanguarda. $\mathrm{O}$ conceito de instauração, por exemplo, como explica Lizette Lagnado (2001), se dá pela junção das atividades ligadas à performance e à instalação, relacionando a incorporação do outro na obra - característica marcante das experiências de 1970 e da contemporaneidade. Hoje, a arte transmidiática de instalação atualiza a imersão no que tange a sensorialidade e a provocação de novos pensamentos, resultando numa imagem-relação que, nos termos de Deleuze (1983), ultrapassa fronteiras; cruza de forma radical o vídeo, o cinema e as novas tecnologias digitais e, assim, diversos caminhos se abrem a novas possibilidades de criação, recepção e percepção das imagens. Essa arte se faz dentro de um cenário de potência inovadora, o qual se revela terreno fértil para investigação crítica devido a uma dinâmica de renovação intensa de experiências. Como afirma Nicolas Bourriaud (2011), aproxima-se do cotidiano e do coletivo de uma maneira menos utópica do que em 1960/1970, pois menos enraizada em estruturas sociais e identidades culturais locais. Ao radicalizar os entre-meios, promove descentramentos espaço-temporais e de narrativa comparáveis às estruturas rizomáticas de Deleuze e Guattari, onde "[...] o rizoma se refere a um mapa que deve ser produzido, construído, sempre desmontável, conectável, reversível, modificável, com múltiplas entradas e saídas, com suas linhas de fuga" (2004, p. 32-33)

\section{Deslocamentos na pós-modernidade}

A antiarte é pois uma nova etapa (é o que Mário Pedrosa formulou como arte pós-moderna); é o otimismo, é a criação de uma nova vitalidade na experiência humana criativa; o seu 
principal objetivo é o de dar ao público a chance de deixar de ser público espectador, de fora, para (ser) participante na experiência criadora. É o começo de uma expressão coletiva [...] (OITICICA, AHO 253.66)

Desde o início do século XX alguns artistas postulavam a inadequação dos meios convencionais, como a escultura e a pintura, dando início a movimentos artísticos de vanguarda de espírito combatente frente à tradição. A reflexão sobre os novos desenvolvimentos tecnológicos, científicos e intelectuais, então, veio acompanhada do uso de novos suportes para suas práticas artísticas, tais como o vídeo, o cinema e os ambientes de instalação. Como observa Arlindo Machado, artistas como Hélio Oiticica, já no Brasil de 1960-70, experimentaram expandir o campo das artes plásticas ao mesclar diversos suportes, produzindo uma obra sem fronteiras, antecipando características da produção da arte contemporânea:

Como se sabe, a partir de meados da década de 6o, muitos artistas tentaram romper com os esquemas estéticos e mercadológicos da pintura de cavalete, buscando materiais mais dinâmicos para dar forma às suas ideias plásticas. Alguns saíram para as ruas e produziram intervenções na paisagem urbana. Outros passaram a utilizar o próprio corpo como suporte artístico e converteram suas obras em performances no espaço público. Outros ainda procuraram mesclar os meios e relativizar as fronteiras entre as artes, produzindo objetos e espetáculos híbridos como as instalações e os happenings. E houve também aqueles que foram buscar materiais para experiências estéticas inovadoras nas tecnologias geradoras de imagens industriais, como é o caso da fotografia, do cinema e, sobretudo, do vídeo. Nos anos 70, Hélio Oiticica introduziu a ideia fertilíssima do quase-cinema, para designar um campo de experiências transgressivas dentro do universo das mídias ou das imagens e sons produzidos tecnicamente. (MACHADO, 2007, p.17)

Para se entender o processo de utilização dos novos materiais dentro de um universo contemporâneo complexo, inicialmente é importante o reconhecimento de como esses artistas começaram a abandonar os suportes tradicionais de arte para fazer uso de novos meios, principalmente os tecnológicos. A partir do final dos anos 1950 e durante a década de 1960, nos EUA, "havia uma inquietude no mundo artístico que se manifestou no surgimento da arte pop, dos experimentos multimí- 
dia de John Cage e de seus colaboradores de Black Mountain College: Robert Rauschenberg, o dançarino/coreógrafo Merce Cunningham e o músico David Tudor." (RUSH, 2006, p.17).

Esta "inquietude", nas décadas de 1960 e 1970, enaltecia a cultura midiática urbana; a exemplo de Nova York (então "capital" da arte no Ocidente), existe agora um contexto que mescla o mundo das celebridades, o glamour, o star system de Hollywood, o rock, a rádio e a TV ao sentimento de inadequação artística dos próprios meios convencionais, impulsionando uma novidade, em tudo transgressora, através da fusão de elementos e posturas condizentes com o clima de instabilidade - mas também criatividade - encontrado, essencialmente, no enorme agrupamento humano da metrópole. No Brasil, a década de 1970 pode ser considerada um dos momentos de contracultura e subversão mais fortes frente ao regime militar, que desde os anos 6o impunha "tempos difíceis" à realidade de um país em vias de modernização. Foi um período em que se privilegiou a desobediência de várias maneiras, desde o engajamento político mais combatente até a cultura das drogas como experiência "libertadora", envolvendo inevitavelmente as novas experimentações com as artes em geral. Nos domínios contraculturais, políticos e, enfim, inquietos deste fazer artístico novo, o momento de ruptura e transgressão rompia com a expressão através de meios tradicionais únicos, geralmente com o fim "passivo" da contemplação, não havendo sentido em continuar com uma arte puramente visual.

As novas tecnologias, como o vídeo e a televisão, se tornaram cada vez mais instrumentos para a criação, aproximando a arte das pessoas, ou seja, da vida que era urbana, tecnológica, subvertendo e se inscrevendo em um contexto politizado, nos quais inúmeros atores sociais marginais (ou outsiders) e suas causas vieram à tona, como é o caso, principalmente, dos negros, das mulheres e dos homossexuais. As experimentações entre-meios se articulam com a intenção de romper com as antigas ideias de representação na obra. Daí o cinema, o teatro, a dança, a música e a literatura, por exemplo, não poderem mais ser classificados separadamente, o que novamente faz mudar - semelhante às experiências de vanguarda do início do século - a definição do que seja uma obra de arte. Em texto do catálogo da mostra Information, ocorrida no MOMA-NY de julho a setembro de 1970, seu curador Kynaston McShine, ao relatar o momento político e social em que 
os artistas de diferentes partes do mundo estavam vivendo à época, remete diretamente aos desdobramentos da definição ou ideia de arte que se processava naquele contexto:

Se você é um artista no Brasil, você sabe de ao menos um amigo que está sendo torturado; se você é um artista na Argentina, você provavelmente teve um vizinho preso por usar cabelos compridos ou por não estar "vestido" corretamente; e se você vive nos Estados Unidos, você pode temer ser baleado ou na universidade, ou na sua cama, ou mais formalmente na Indochina. Pode parecer muito inapropriado, ou mesmo absurdo, levantar-se de manhã, entrar numa sala e aplicar pinceladas de tinta vinda de um pequeno tubo a uma tela quadrada. $\mathrm{O}$ que você pode fazer como jovem artista que lhe pareça relevante e significativo? [...] uma alternativa tem sido estender a ideia de arte, renovar sua definição, e pensar para além das categorias tradicionais - pintura, escultura, desenho, gravura, fotografia, teatro, música, dança e poesia. (1970, p. 138)

As primeiras instalações com vídeo são creditadas aos artistas do final da década de 1950 e durante os anos 1960. De acordo com Michael Rush (2006), a arte da instalação teve início com as vanguardas sessentistas, que eram contrárias a instituições de arte, museus e galerias. O mercado da comunicação em massa, ou seja, a visão unilateral e restrita da televisão broadcast era o principal alvo da crítica desses artistas, que usavam o mesmo suporte para construírem suas instalações com vídeo - como no caso da construção dos ambientes videográficos a partir da utilização de monitores de TV. O próprio Rush afirma que Wolf Vostell e Nam June Paik foram os primeiros a usarem o vídeo fora dos estúdios televisivos. Como uma nova forma de expressão, Vostell prima por criar ações dentro de ambientes construídos, que são eventos ocorridos para participação de todos. Em seu Manifesto What I Want, de 1964, escrito na ocasião do evento de arte da Aachen Tecnical University, na Alemanha, ele discorre sobre suas intenções:

...nenhuma diferença entre vida e arte/

...escapar não da mas na realidade/

...fazer do happening uma experiência sentida no próprio corpo/

...tornar-me cor, luz, tempo, matéria e pintura/ 


\section{$[\ldots]$}

...tirar cada cena da vida cotidiana de seu contexto costumeiro e situá-las em um novo contexto/

...participação permanente em todos os procedimentos com os sentidos do toque, cheiro etc./ ...caracterizar um evento através da soma de efeitos colaterais/

...arte como espaço, espaço como ambiente, ambiente como evento, evento como vida/ ...viver arte e pensar arte/

...objetivo, sem objetivo, forma aberta, ausência de centro, conquista de um objetivo, sem foco/

...todos como performers ou executores no lugar de observadores ou ouvintes/ (VOSTELL, 2012, p. 58-59)

No âmbito das experimentações que aconteceram no Brasil, destaca-se dois artistas que deram continuidade às práticas de ambientes instalativos transmidiáticos, conduzindo as práticas cinematográficas e videográficas a novas formas de relacionamento: Wesley Duke Lee e Hélio Oiticica.

Os trabalhos ambientais de Wesley Duke Lee O Trapézio ou Uma Confusão, de 1966, e Gaiola de Cadeiras, de 1967, deram origem, pouco tempo depois, à videoinstalação $\mathrm{OHe}$ licóptero (1967-1969). Trata-se de um espaço criado por um circuito fechado de vídeo, um espelho, pinturas, colagens, sons, luzes, cadeira de piloto, painel de controle de aeronave, entre outras coisas, segundo Cacilda Teixeira da Costa, "pensado como um meio de levar o espectador/participante a uma viagem que o iluminaria sobre seu espaço interior" (COSTA, 2005, p.148). As imagens das pessoas que transitam pela instalação são refletidas no espelho e também são exibidas na tela da televisão, "lembrando a concepção de McLuhan de que o espelho e o vídeo representam diferentes ângulos de consciência: o sincrônico e o diacrônico" (COSTA, 2005, p.148). O universo de Wesley Duke Lee, desde as instalações mais simples até as mais complexas e tecnológicas, situam-se nos desdobramentos do futurismo italiano de Marinetti (conforme exploração da relação humana com os modernos recursos e possibilidades da máquina), fazendo com que o artista se inspirasse nesta vertente para construir ambientes multimídia, ainda através da união de diversos materiais e objetos que interviriam nas experiências sensoriais do público. As luzes e os sons de $O$ Helicóptero e seus elementos cinéticos afetam a imaginação e distorcem a noção de tempo e lugar, abrindo outras percepções e realidades ao participante. 
Além desta instalação de Duke Lee, os trabalhos de arte ambiental de Hélio Oiticica, que se iniciaram com os Penetráveis (1960) e os Parangolés (1965) e que o levaram a criar, em 1967, o ambiente instalativo híbrido Tropicália - PN2 "A Pureza é um mito", $\mathrm{PN}_{3}$ "Imagético", deram início à construção dos ambientes midiáticos sensoriais que, então, fariam parte do seu processo de trabalho durante a década de 1970 - os quase-cinemas. Criado em 1967 e constituído por dois Penetráveis (PN2 e $P_{3}$ ), além de plantas tropicais, papagaios, areia, brita, poemas objetos, ervas aromáticas e uma televisão de 14 polegadas ligada permanentemente, em Tropicália Oiticica opera mecanismos do vídeo, do cinema experimental, da instalação ambiental e da participação do público: as "estruturas comportamento-corpo", segundo sua própria definição (0409/72, p. 1).

\section{Fluxus: ideias-mundo erigindo invenções}

Sob a liderança de George Maciunas, o Grupo Fluxus era constituído por artistas, cineastas, músicos e atores de diversas partes do mundo; dentre eles, transitaram pelo grupo Joseph Beuys, Wolf Vostell, Nam June Paik, Bem Vautier e Yoko Ono. Para Rush, Fluxus era "um movimento 'entre meios de expressão"” (2006, p. 18): críticos, provocativos e mergulhados em humor irônico, esses artistas tentavam ampliar as mais variadas formas de expressão. Ao integrar diferentes linguagens, sobretudo tecnológicas, a manifestação da arte se dava através de happenings, performances, filmes, instalações e vídeo-arte: "a arte deve parecer complexa, pretensioso, profunda, séria, intelectual, inspirado, hábil, significativa, teatral" (MACIUNAS, 1965, s./p. tradução nossa). Suas realizações compõem objetos, sons, movimentos e luzes, onde os sentidos do espectador são convocados. Suas experimentações não possuem sequências pré-estabelecidas de atos; assim, o público pode (deve) ir para qualquer lugar, para onde desejar. A participação aqui é condição primária para a construção e constituição de obra, pensamento e vivência. Pode-se dizer que se trata de arte ambiental que, a partir de objetos e ações diversas, intentam desestetizar, destruir a imagem "sagrada" do objeto pronto, sendo obra aberta à participação do público que se encontra imerso na recepção ativa.

Influenciado pelo dadaísmo - em especial pela obra de Marcel Duchamp -, Fluxus contrariava a política elitista dos museus e galerias de arte, bem como a ideia romântica de que 
o artista, individualizado em sua inspiração sagrada, é o único detentor da capacidade de produzir arte. No Manifesto escrito em 1963 há frases que revelam uma postura inconformista radical, como em "destruam os museus de arte" (que lembra também a revolta contra o passado dos primeiros manifestos futuristas de Marinetti) ou "destruam a cultura séria". Como Duchamp com seus ready-mades, esses artistas se apropriavam de objetos industrializados e produzidos em massa, que faziam parte do cotidiano, e os expunham em instituições artísticas, atribuindo a eles o status de obra de arte. Ironizavam o objeto artístico consagrado e, assim, tinham a intenção de reduzir todas as criações artísticas ao plano dos objetos comuns, criando o conceito de antiarte. Para os artistas do Fluxus, a arte deveria ser retirada dos museus e instituições e inserida no cotidiano das pessoas. Opondo-se à produção de obras individuais, pregavam a criação coletiva, onde qualquer pessoa poderia entender e criar arte, se aproximando do Construtivismo Russo, por exemplo, no que se refere à função social e à participação na política por parte dos artistas. Daí o museu, para o grupo, representar por excelência a instituição construtora de padrões que, em sua estrutura original, deveriam ser inquestionavelmente seguidos, não permitindo que aos artistas a proposição de obras que se aproximassem da vida, no sentido do comportamento existencial das pessoas.

Com espírito dadaísta, os fluxistas negavam os padrões estabelecidos, pregavam a antiarte e evocavam a desmaterialização do objeto de arte e a participação do antigo público contemplador, movimentando ideias, corpos, lugares e tempos em um universo onde o processo criativo acontece através da destruição da fronteira entre a arte e a vida, junto à construção de percepção e pensamento novos. Para eles havia um vínculo que era primordial para a manifestação da arte: os objetos cotidianos, os eventos e a própria arte. Dessa forma, concretizavam a ideia através de performances minimalistas, mas que eram acessíveis a qualquer pessoa, pois se tratavam de eventos-ações sobretudo não elitistas. Os eventos fluxistas possuíam, então, instruções para performance, deixando ao acaso as inúmeras possibilidades de interpretação: a obra estava aberta às possíveis eventualidades que ocorreriam devido à participação. Tal evento, como definido por George Brecht,

era a menor unidade de uma situação. Um deles, concebido pelo artista Mieko Shiomi, foi descrito como "um evento 
aberto" - simplesmente "um convite a abrir algo fechado". Pediu-se aos participantes que escrevessem exatamente o que havia acontecido durante o "evento". Essa simples tarefa tornou-se um manifesto contra a arrogância da arte em museus, bem como uma ação participativa porque as pessoas se reuniram para realizá-la. (RUSH, 2006, p.18)

\section{Fluxfilms}

Os fluxfilms são, no total, 40 filmes curtos, feitos na maior parte das vezes por artistas, e não por cineastas, cujas referências estéticas incluem a poesia concreta, a arte dadaísta e a música experimental de Arnold Schönberg. Rejeitando a imagem tradicional e consagrada das obras de arte, artistas do Fluxus produziam filmes que traziam significado para os objetos comuns. Ao criarem filmes minimalistas, sem história narrativa complexa e com ações repetitivas, colocavam em questão as associações habituais do espectador contemplativo. O fluxfilm Zen for Film (1962-64), de Nam June Paik, foi apresentado no apartamento de Maciunas em Nova York, denominado fluxhall, como um evento que misturava instalação, filme e performance: uma tela caseira disposta na parede como se fosse uma pintura, um piano e um contrabaixo. O filme dava pouca importância à grande - $\mathrm{e}$ caríssima - indústria cinematográfica hollywoodiana (no fundo, era em tudo contrário a ela). Não por acaso, na tela foram projetados trinta minutos de película $(16 \mathrm{~mm})$ em branco, onde o mínimo elementar era a película, a projeção na tela sem alguma imagem. Paik haveria insuflado "um aspecto de performance no contexto da tela e, ao fazê-lo, libertou o observador das manipulações tanto do cinema comercial quanto do cinema alternativo" (JENKINS, ANO apud RUSH, 20o6, p.19). O objetivo dos fluxistas era eliminar qualquer condicionamento possível que poderia desenvolver um filme de narrativa linear para ser assistido por um espectador inerte em uma sala de cinema.

\section{Quase-cinemas: Hélio Oiticica e Jack Smith}

[...] será necessária a criação de "ambientes" para essas obras - o próprio conceito de exposição no seu sentido tradicional já muda, pois de nada significa "expor" tais peças (seria aí um interesse parcial menor), mas sim a criação de espaços estruturados, livres ao mesmo tempo à participação e invenção criativa do espectador. (OITICICA, 1986, p.76) 
Hélio Oiticica, ao longo de sua trajetória artística, manteve como horizonte filosófico e estético a aproximação entre a arte e a vida, buscando expandir os objetos em sua relação com os espaços e, com isso, os fazendo interagir com o público. Nesse sentido, a criação de ambientes propícios para a invenção do público - que para Oiticica são participantes criativos - ativa o conceito de "suprassensorial" proposto por ele a partir de 1965 , que é manifestação coletiva desencadeada pela reunião de elementos diversos: os ritmos das músicas (sobretudo o samba e o rock), a dança, o uso das drogas e os mitos. Esta ideia se expande e se potencializa de várias formas em seus trabalhos e na vida dos participantes, que passam por instantes de criação livre ao adentrar nas ambientações híbridas e acessar seu direito à liberdade patente no ato criador - o que transforma sua visão de mundo. Para tanto, o programa de Oiticica tem como característica substancial a supressão do isolamento da obra de arte no museu, fazendo-a vir ao público que, por sua vez, precisa participar da obra para que ela se construa:

Quando proponho um shelter ${ }^{2}$ para a época de minha obra de MANIFESTAÇÃO AMBIENTAL, na verdade proponho o fim do 'museu'ou da 'coleção privada', ou melhor, quero mostrar que essas obras não se destinam a esses fins. (OITICICA, PHO 0316/73, p. 9) 3

Em 1968, Oiticica escreve sobre o projeto Barracão, cujo objetivo seria o de construir uma casa em madeira, à semelhança de barracos da favela, "onde as pessoas a sentiriam como se fosse o lugar delas, talvez nas montanhas perto daqui, onde $o$ meu grupo iria para fazer coisas, conversar, conhecer pessoas" (OITICICA, 1996, p.135). Este teria surgido através da necessidade de expandir a corporalidade dos Parangolés em direção a um espaço arquitetural para lazer inventivo (o conceito de Crelazer aqui se radicaliza). A ideia era a de transformar a moradia em obra aberta para "experimentações-limite" (e não para construção de obras) através da vivência individual em um ambiente coletivo, cuja estrutura formasse um todo "corpo-ambiente". O projeto não foi realizado naquele momento no Rio de Janeiro, porém a ideia de viver em permanente estado de lazer inventivo se concretizou quando Oiticica, em Nova York na década de 1970, transformou os dois apartamentos em que morou em "ninhos" para convivência e deleite dos amigos que o visitavam. Os ambientes penetráveis construídos a partir de grandes beliches 
de madeira eram repletos de objetos a serem manipulados, aparelhos de som, televisão, livros e assim por diante.

As vivências criativas propostas por Oiticica podem ser comparadas com as que aconteciam no apartamento de Jack Smith ${ }^{4}$. Após ter passado oito anos trabalhando com o cinema tradicional, a partir da década de 1970 Jack Smith começou a incorporar performances a seus filmes, a trabalhar objetivando a desconstrução do dispositivo cinema através dos slides, além do uso de multiprojeções, antecipando, assim, aquilo que Gene Youngblood (ainda em 1970) denominaria Cinema Expandido. Nos eventos, ele projetava nas paredes de seu apartamento recombinações de imagens de slides e de seus filmes, ambos misturados, e muitas vezes editava as películas ao vivo usando fitas adesivas (antecipando também o Live Cinema). Ao mesmo tempo, construía sons com vinis e fazia uma ação teatral ao vivo. Não havia roteiros, tudo se passava de maneira espontânea, casual. As pessoas que frequentavam seu apartamento se sentiam parte integrante da performance.

Oiticica, por sua vez, sempre buscando a desativação dos meios tradicionais de expor e contemplar arte, chega a um radicalismo limite na década de 1970, quando somou a seu programa ambiental as ideias de rompimento com a estrutura tradicional do dispositivo cinema. A obra cinematográfica de Hélio Oiticica, os quase-cinemas, é permeada por diversas linguagens, como a fotografia, o cinema e o som, tratando-se de instalações multimídia, ambientações imersivas com projeções de slides e objetos a serem manipulados para a efetiva participação do público-visitante. A projeção de slides era acompanhada de instruções a serem seguidas pelo público, trilha sonora e objetos do cotidiano, como redes, areia, lixas de unha, panos, estopas etc., que formavam um ambiente sensório atraente para o participante. Assim como as caixasfluxus (os fluxkits), Oiticica fez uso de ferramentas táteis produzindo uma série de explorações multissensoriais, estimulando o senso individual de participação ao unir - e libertar, como acreditava - arte e vida.

O próprio Oiticica faz referência a Jack Smith, que também trabalhou com slides e da forma como ele almejava, isto é, com performance e elementos casuais. Na realidade, a primeira vez que cunhou o termo quase-cinema foi para descrever um dos eventos de Jack Smith denominado Travelogue para Atlantis (ocorrido em $1971 \mathrm{em}$ seu loft em Nova York). Entusiasmado com a performance, escreveu em seguida para Waly Salomão dizendo que 
coisas decisivas aconteceram essas duas últimas semanas! jack smith: fui lá; tudo aconteceu e só o vi depois numa sessão de slides com sound track que foi maravilhosa...no dia dessa projeção... era êsse o ambiente: chamava-se "travelogue of atlantis" e estava marcado para sete e meia da noite; bem ...tudo começou às dez horas depois, e só nos três primeiros slides êle ficou meia hora: mudou a tela de lugar, de modo que os slides sofriam um corte ao serem projetados, e êle movia o projetor de lugar pra dar o corte devido a cada um: o resto do slide se espraiava pelo ambiente: incrível; a espera e a ansiedade que me dominou, valeram: foi uma espécie de quase-cinema, pra mim tão cinema quanto tudo que se possa imaginar... (1111.71, pp. 1-2 AHO/PHO)

Destarte, os eventos de Jack Smith em seu apartamento e o programa ambiental de Hélio Oiticica, sobretudo os quase-cinemas, certamente se revelam como uma obra híbrida, transmídia de instalação, aberta à participação e ao conhecimento através da incitação sensório-cognitiva na recepção.

\section{O cinema expandido}

Quando dizemos cinema expandido queremos dizer na verdade consciência expandida.Cinema expandido não significa filmes de computador, fosforescência de vídeo, luz atômica, ou projeções esféricas. Cinema expandido não é mesmo um filme: como a vida é um processo de tornar-se, o curso histórico do homem conduz o manifesto de sua consciência fora de sua mente, na frente de seus olhos. Não há mais quem possa mais se especializar numa única disciplina e esperar sinceramente expressar uma imagem clara das suas relações no ambiente ${ }^{5}$. (YOUNGBLOOD, 1970, p. 41, tradução nossa)

À luz da era cibernética e para explicar as experiências dos anos 1970 que uniam cinema, vídeo e tecnologia digital, Gene Youngblood cunhou o termo "cinema expandido". Menos utópico, André Parente acredita que o cinema expandido enquanto "processo de desocultamento do dispositivo do cinema e da produção de uma imagem processual, aberta, que envolve o espectador" (2011, p.31), caracteriza-se, sobretudo, por duas ideias centrais. De um lado, consiste em instalações que rompem com a sala escura do cinema tradicional, reinventando o cinema em outros espaços expositivos - o cinema através da união da caixa preta do cinema e do cubo branco dos museus 
e galerias, de onde insurge a sua segunda vertente: a hibridização entre os suportes. Para Parente, "enquanto o cinema experimental se restringe a experimentações com o cinema e a videoarte se notabiliza pelo uso da imagem eletrônica, o cinema expandido é o cinema ampliado, o cinema ambiental, o cinema hibridizado." (2009, p. 25)

Dessa forma, o conceito de cinema expandido se instaura através de uma série de trabalhos experimentais que criticavam os mecanismos tradicionais do dispositivo cinematográfico, principalmente através da "multiplicação dos níveis de projeção, abolição das fronteiras entre diferentes formas de arte, retorno à corporalidade, desconstrução das técnicas fílmicas e a criação de obras de arte feitas de pura luz" (SANTAELLA, 2003, p.162). O cinema tradicional é então substituído por essa nova forma de se fazer cinema, que redimensiona a arquitetura do espaço expositivo através das multiprojeções, por exemplo, explorando outras durações e fazendo com que o espectador, ao se deslocar, também recrie o cinema. Segundo Nina Velasco e Cruz: "O espectador passa a ter mais mobilidade diante da tela, rompendo com a sensação de imersão completa que o abandono do corpo na escuridão procura permitir." (2009, p. 53). Ao imergir o antigo espectador do cinema tradicional em um ambiente diferenciado, propõe-lhe uma nova fruição estética e desperta sua inteligência crítica. A trama sensorial, física e cognitiva, se estende à multiplicidade do espectador, aqui entendido como coautor da obra.

\section{A condição "transmedium" na arte contemporânea}

Dick Higgins, em 1966, utilizou a palavra-conceito intermédia para explicar seus trabalhos e de seus colegas do grupo Fluxus. Para ele, a intermédia, em contraponto ao conjunto de obras feitas a partir de apenas um médium, compreendia as manifestações de arte que faziam o uso simultâneo de linguagens artísticas plurais que, uma vez unidas, não poderiam mais ser entendidas separadamente, pois compunham um fluxo único de criação, num movimento contínuo de transmutação. Assim, todos os médiuns engajados na formação da obra, apesar de possuírem sua riqueza e contribuição particular para o todo, são interdependentes, formando uma "máquina" que incorpora potências de liberdade e experimentação.

O conceito de transmídia no campo da arte aqui proposto atualiza e ultrapassa o conceito de Higgins, ao levar ao limite a 
noção de fluxo de criação na hibridação dos meios arte, cinema e vídeo, num entendimento de movimento contínuo de transmutação que atravessa, ainda, as mais novas tecnologias audiovisuais. Assim, preferiu-se definir os dispositivos apresentados como uma prática transmídia, em detrimento de multimídia, intermídia ou crossmídia. O prefixo inicial "trans" - "além de", e acordo com sua origem no latim -, pode também significar "outro", denotando, assim, para além de sua etimologia, a arte transmídia como agenciamento de médiuns completamente amalgamados entre si e que formam um dispositivo complexo para fruição e imersão na recepção. Assim, em transmídia entende-se que a palavra mídia significa médium (meio) e opõese à mídia como mass media. Além disso, a mídia não é mero suporte técnico, mas um elemento-dispositivo de efetivação na obra em suas dimensões técnicas, estéticas e poéticas. Devido a uma nova conjuntura de práticas contemporâneas que se desenvolvem na "fundição" de médiuns e que exploram dispositivos inovadores como as novas tecnologias audiovisuais (para captação de imagens, manipulação, apresentação e arquivamento), torna-se necessária uma nova reflexão sobre o médium, que não é mais absoluto em sua pureza estética e formal. O médium é outro, ele é "transmedium".

No "ambiente mediatizado/construído em jogo com o propósito da reflexão" (MORSE, 1990, p.158) da arte transmídia de instalação, o campo imagético é organizado de maneira que "a imersão é um princípio estético" (MELLO, 2008, p. 170). Nos entre-fluxos do cinema, do vídeo, das artes plásticas e das novas tecnologias ocorre a modificação do espaço-tempo e a exploração de imagens "transnarrativas" (de narrativas outras, não lineares). Diferentemente das salas de cinema que "prendem" o público a seus lugares, bem como dos museus e galerias que expõem objetos para contemplação visual e passiva, entende-se que a arte transmídia de instalação audiovisual fornece um espaço de abertura constante do campo perceptivo, favorecendo para que o participante, na recepção, "viva" a obra com seu corpo e mente, fazendo insurgir nele suas próprias referências de vida, num acometimento de sentidos. Ora, uma vez que a arte transmídia de instalação opera trânsitos com o outro, seus procedimentos evidentemente atuam entre $o$ individual e o coletivo, passando a se estruturar na própria experiência de vida do participante, na sua realidade, nos seus sonhos, e assim por diante: "Expandem-se assim [...] as fronteiras entre o documentário e a ficção, o visível e o sugerido, o vivido e o imaginado." (MELLO, 2008, p.183). 
$\mathrm{Na}$ cena internacional, alguns dos artistas/cineastas transmídia mais relevantes que trabalham dentro do presente conceito de arte transmídia são: Apichatpong Weerasethakul (Tailândia), Philippe Grandrieux (França), Zoe Beloff (UK) e Mark Lewis (Canadá). Em âmbito nacional, alguns dos mais representativos nesse domínio seriam Eder Santos, Adriana Varella (ainda que trabalhe em Nova York), Lucas Bambozzi, Kika Nicolela, Luciano Mariussi, Caetano Dias, Giselle Beiguelman, Fernando Velázquez, Maurício Dias e Walter Riedweg, entre outros. Tais artistas e cineastas, cada um à sua maneira, e muitas vezes levando ao extremo a interação e a imersão do público através de novos códigos midiáticos e tecnologias audiovisuais, relativizam os meios da arte, do cinema e do vídeo ao construírem ambientes situacionais que propõem trânsitos e situações transformadoras.

É importante salientar que a estética da arte transmídia contemporânea tem, em suas práticas, uma orientação ética enquanto união da arte com a vida. Distancia-se, porém, do sentido explorado pelos artistas vanguardistas quando construíam suas obras na "forma utópica da obra de arte total”, o gesamtkunstwerk, objetivando transformar o mundo na visibilidade de uma revolução politizada. A tendência contemporânea é agenciar códigos e signos do cotidiano, da cultura e de outros campos do conhecimento criando "alteridades possíveis” (BOURRIAUD, 2011, p. 168), sobretudo em espaços heterotópicos ${ }^{6}$.

No Brasil, a efetiva criação de potências na arte transmídia, desde 1960 até os dias atuais, é alimentada por situações de mescla social e cultural, por ações "antropofágicas" (no sentido oswaldiano de deglutição de conceitos e práticas vindos do exterior) e por se viver o underground como única situação possível devido ao ainda encarecimento do material audiovisual no país, que não permite que a tecnologia seja amplamente aproveitada por todos. Os processos criativos dos artistas são considerados autônomos em oposição ao que comumente designava-se como "arte brasileira", pois se alinham com o contexto da arte contemporânea ao contaminar suas práticas com códigos provenientes de outras culturas e de outros campos de conhecimento. Mas, ainda assim, carregam todo o conteúdo histórico, social e econômico que dinamizaram o país. Portanto, a arte transmídia de instalação produzida no Brasil atualmente possui singularidades importantes a serem consideradas, uma vez que constroem um campo simbólico particular no seu contexto específico, 
dialogando, ainda, com as principais tendências e práticas da arte contemporânea global. Pela pluralidade e potência de aparatos, conceitos e práticas presentes, nos deteremos em dois trabalhos recentes de dois artistas expoentes de contemporaneidade transmídia: André Parente e Kátia Maciel.

\section{Situação-cinema: o cinema-outro de André Parente e Kátia Maciel}

\section{André Parente: Circuladô}

Para o perfeito flâneur, para o observador apaixonado, é um imenso prazer fazer sua casa no numeroso, no ondulante, no movimento, no fugitivo e no infinito. Estar fora de casa e sentir-se em casa em todos os lugares; ver o mundo, estar no centro do mundo e permanecer oculto ao mundo ${ }^{7}$. (BAUDELAIRE, 1863, tradução nossa)

André Parente é artista, cineasta, pesquisador e professor da Universidade Federal do Rio de Janeiro (UFRJ), onde fundou o grupo de pesquisa $\mathrm{N}$ - Imagem (Núcleo de Tecnologia da Imagem), que explora os cruzamentos da arte, do cinema e das novas mídias digitais. Sua obra, carregada de filmes, vídeos e instalações, se situa nas contaminações do cinema com a arte, a filosofia e as novas tecnologias. Em constante diálogo com a sua produção escrita, seus trabalhos, mesmo tocados por instrumentalizações de outros meios, continua, para o artista, a ser cinema. Um cinema-outro, é verdade, uma vez que, invadido por outros meios, espacializa imagens, desconstrói narrativas e modifica temporalidades.

Parente trabalha entre duas temporalidades: a primeira se relacionada ao pré-cinema, e procura a essência do dispositivo cinematográfico esmiuçando todas as sutilezas intrínsecas a esse fazer; a segunda, numa reflexão de pós-cinema, investiga suas contaminações e possibilidades por meio do uso das mais novas tecnologias. Assim, Parente promove uma sorte de epistemologia do cinema ampliado através do estudo aprofundado de suas técnicas, conceitos e procedimentos que criam subjetivações nas brechas dos dispositivos. A reflexão de Parente, sistemática e de grande riqueza para a arte contemporânea no contexto da transmídia, se faz presente em "Circuladô" (2010-2014), instalação construída a partir da articulação de imagens de arquivo de cinema. 
Exposta pela primeira vez no Museu da Imagem e do Som de São Paulo, em 2011 ${ }^{8}$, esta obra explora novos suportes tecnológicos numa organização espacial que propicia a interação: sensores analógicos de rotação para capturar o movimento do participante, programado no ambiente de programação Isadora ${ }^{9}$, placas de vídeo TripleHeadTogo para a projeção e um sistema de som 5.1 surround para que possa se deslocar em 360\%; isso, em um amplo espaço circular de 6 metros de altura por 18 metros de comprimento. As grandes projeções em diversas telas circundam o participante, dando a impressão de se estar dentro de um grande Zoetrope. ${ }^{10} \mathrm{O}$ público, inserido na situação da obra, interage quando o artista coloca à sua disposição, no centro do espaço, um objeto designado como "giroscópio", que permite a manipulação das imagens fornecidas previamente. Através dessa interface, pode-se alterar a velocidade das imagens e o deslocamento do som, que giram ambos ininterruptamente.

O impulso poético de André Parente, ligado a seu modo de fazer, surge a partir do que ele denomina como "atravessadores". Trata-se de momentos, fatos ou coisas, como a música, a literatura, o cinema e a dança, por exemplo, que cruzam a vida e que trazem, na surpresa do acaso, sentidos. Estas circunstâncias e coisas que permeiam a existência são, segundo ele, como a própria vida, cujos acontecimentos surgem, desaparecem e ressurgem, em um ritmo circular: "[...] repetições, rotações, círculos, ciclos - somos surpreendidos pela 'natureza' periódica da vida, até o mais recôndito da nossa experiência interior, bordada que ela é sobre a trama de nossa respiração, de nossos hábitos, de nossa espera, de nossos mecanismos e loops mentais." "Já há muito tempo o gesto do giro chama a atenção do artista e, em "Circuladô", tudo efetivamente gira: os personagens, o "giroscópio" e, por fim, as mãos e os olhos do participante, assim como todo o seu corpo - se assim o desejar. As imagens dos personagens em giro presentes são Édipo, Corisco e Dervish e foram retiradas, respectivamente, dos filmes "Edipo Re" (Pier Paolo Pasolini), "Deus e o Diabo na Terra do Sol" (Glauber Rocha) e "Decasia" (Bill Morrison). Quando eles rodopiam em torno de si mesmos estão em uma "situação-limite". O ato de girar, em uma dimensão filosófica, traz temas de interesse a Parente, como destino, morte, transe e loucura.

No filme do Glauber, o Corisco acabou de receber um tiro, ele gira e cai morto. No Édipo, ele acaba de ouvir do oráculo que ia 
matar o pai e ficar com a mãe, então ao aparecer a primeira encruzilhada ele põe a mão nos olhos para não escolher, gira e vai na direção em que para, porque acha que se escolher vai acabar caindo nas armadilhas do destino. (PARENTE, 2014, s./p.)

Usando o corpo do espectador como elemento ativo para criação nas brechas dos médiuns-dispositivos, a subjetivação na obra de André Parente nasce na articulação de elementos que se transformam a cada experiência do participante-criador: "Circuladô" é um ambiente para imergir, estruturado com elementos diversos a serem manipulados: objetos, imagens em movimento, música. Parente imprime em seus percursos a superação da arte contemplativa, aquela da representação, para estruturar práticas da arte contemporânea nas quais estão embutidas as experiências da vida individual e coletiva como proposição da arte, em detrimento do olhar sobre uma imagem, deflagrando vários caminhos de criação. O corpo segue um trajeto de infinitas possibilidades ativando nele a subjetividade de um flâneur, que é envolvido e envolve a obra. Trata-se do flâneur de Charles Baudelaire, aquele que está, ubiquamente, imerso no mundo exterior e em seu âmago.

\section{Kátia Maciel: Suspense}

O cinema é sempre cinema quando é um dispositivo de construção de imagem e subjetividade. No sentido bergsoniano somos todos imagens entre imagens. A arte tem sido na contemporaneidade a forma de atualização de cinemas experimentais e expandidos. Se muitas vezes estiveram misturados, agora cinema e arte são indiscerníveis. ${ }^{12}$

Kátia Maciel é artista, poeta, curadora, crítica de arte, pesquisadora e professora da Faculdade de Comunicação da UFRJ: uma "artista-etc" como disse Ricardo Basbaum, definindo a tendência plural do artista contemporâneo. Nos entre-meios do cinema, do vídeo, da arte e das novas tecnologias audiovisuais, ela produz instalações bastante expressivas que radicalizam processos experimentais de arte-vida alinhados aos procedimentos menos utópicos da arte contemporânea. Trata-se de dispositivos de transcinemas, nome-conceito que criou e desenvolveu para explicitar a sua e outras produções, cuja construção se dá através da transmidialidade audiovisual de instalação com o fim de propiciar a participação, sendo uma nova forma de se fazer cinema. Nas palavras da artista: 
Transcinemas foi um meio que eu criei para dar conta de um campo contemporâneo, da Arte Contemporânea, que é esse cinema expandido pelas instalações. Então, "trans" é de "além de". Assim, tem uma forma de cinema ainda - algumas instalações pegam desde a relação com a própria imagem e movimento, com as narrativas, multiplicação das narrativas, multiplicação das formas de interagir com essas narrativas. (CARRAPATOSO, 2010, p.194)

Os espaços de "situações-cinema" criados por Maciel exploram procedimentos do cinema que reagem à maleabilidade e casualidade próprias do vídeo e às novas tecnologias de montagem e edição, as quais potencializam a recepção numa experiência estética onde o corpo é expandido no espaço como imagem. O modus operandi da artista abarca

entrecruzamento de narrativas, efeitos, sequenciamentos, ações corporais e vozes: há já um corpo de obra e conjunto de experimentos que trazem um fio sinuoso de espessura própria, onde se materializam as inquietações e problematizações de uma poética. (BASBAUM, 2014, p. 59)

A poética da artista se divide no que ela chama de "desnaturezas" e "desnarrativas amorosas". Na etimologia, o prefixo "des" se refere à separação ou à uma ação contrária: desfazer algo. Maciel costuma dizer que não filma o que vê, mas vê o que filma, negando uma suposta representação da verdade; a imagem vista no filme nunca é realidade, ou melhor, sua re-apresentação no filme implica subjetividade. Quando apresentadas no espaço expositivo, o campo imagético, mais do que um efeito, convida à experimentação em heterotopias imersivas que, em suas contradições, assim como a vida, constroem múltiplas narrativas e potencializam a existência na presentificação do tempo. Uma exposição de cinema expandido recente, ocorrida na Zipper galeria em São Paulo, é "Suspense" (2013).13 Trata-se de uma instalação de "desnatureza" que funde médiuns no percurso e recepção da obra: "Vulto" (vídeo-performance), "Suspense", "Espreita" e "Espera" (fotografia), "Caixa de ar" e "Caixa de luz" (objeto/poema visual), “Tocaia”, "Vestígios”, “Cálculo”, “Teoria”, "Perspectiva”, "Vertigem" e "Abrigo" (conjunto de oito lambe-lambes). ${ }^{14}$

No vídeo "Vulto", a câmera fixa mostra a artista mise en scène em meio a uma floresta, por ondecaminha e, em um segundo momento, surge amarrada pelas mãos pendurada em uma árvore, 
balançando; um corpo transformado em pêndulo, como se marcasse o tempo. A repetição do mesmo movimento do corpo simultaneamente presentifica o tempo, representando o infinito possível no corpo, suspendendo temporalidades: na iminência de um encadeamento de narrativa, ainda não se sabe o que acontecerá, é um acontecimento em suspenso. De natureza bergsoniana/deleuziana, assim como em André Parente, a dimensão subjetiva na obra da artista pensa a imagem na interioridade do tempo durativo, que não é o tempo cronológico. Em Maciel, o caráter absoluto da imagem em movimento é relativizado por essa imagem-tempo dinamizada na repetição - uma estética recorrente no conjunto de sua obra, segundo afirma:

Como repetição registro o retorno do tempo. Há uma mudança que opera nos dois sentidos da ação. A imagem mostra a operação de ida e volta de uma ação ou alteração do estado de um objeto. Com a repetição o fim é o começo e o começo o fim. Repetir faz ver o que há e não é visto. ${ }^{15}$

Em outro momento, retirado de uma entrevista para um jornal francês na ocasião de sua exposição "Répétition" na Maison Européenne de la Photographie de Paris, em 2014, a artista fala sobre a questão da repetição relativizada pela imagem-tempo:

A ideia de repetição se manifesta na grande maioria dos meus trabalhos onde o tempo parece resistir ao tempo. Em Meio cheio, meio vazio, eu despejo a água de uma garrafa em um copo que sempre permanece preenchido até a metade. O paradoxo contido neste trabalho é baseado em nossa relação com o tempo; o instante é percebido como uma duração em razão da utilização do loop da imagem. É, então, a expressão do que passa e, ao mesmo tempo, do que permanece. O instante é percebido como um fluxo contínuo e não como unidade estática. [...] Para a maior parte dos meus trabalhos eu utilizo um plano fixo e um enquadramento específico no objeto filmado. Se há movimento, ele se abre frequentemente no interior da imagem. É então na edição que se cria um diálogo ou uma fricção entre os diferentes planos que compõem o espaço-tempo da imagem. ${ }^{16}$

Além da projeção, "Suspense" compreende um espelho posicionado em frente ao jardim da galeria que captura, em tempo real, a imagem refletida, isto é, o jardim e as pessoas que por ali passam. As pessoas podem se observar no espelho e, simultaneamente, sua imagem é projetada em tempo 
real em seu verso, uma tela de projeção disposta de maneira perpendicular à projeção central, ("Vulto"). Também em entrevista, Maciel diz que

\begin{abstract}
implicar o espectador no que se vê é muitas vezes um elemento estrutural nos meus trabalhos. Na instalação Verso, a própria construção da imagem e a sua disposição no espaço instalado tornam o visitante parte da paisagem. Desfazer, interromper, reconfigurar, alterar, deslocar o que seria da ordem da natureza é uma constante nas imagens que construo, é retornar ao ver e ser visto, desviando e distorcendo esta operação sensível, simbólica e estética. ${ }^{17}$
\end{abstract}

Há ainda fotografias da artista na floresta que, por sua natureza, paradoxalmente radicalizam a suspensão do tempo na visibilidade da infinitude subjetivada na memória, além de dois objetos/poemas visuais, a "caixa de luz" e "caixa de ar", caixas transparentes que se referem, respectivamente, ao elemento primordial da sala escura do cinema e com a noção de intangibilidade. Completa-se a narrativa com a apresentação em lambe-lambe dos cartazes prévios da exposição, no impulso de mostrar para o público, metalinguisticamente, a montagem ficcional da exposição.

Nesse universo sensorial, o corpo do participante, expandindo como sujeito ativo na obra, é também um meio, uma imagem na interioridade do tempo, uma forma-tempo. Ele se relaciona com o passado virtual através de sua memória e implica-se no real como participante cocriador. O tempo da situação-imagem, tal como o teorizou Gilles Deleuze e, primeiramente, Henri Bergson, está entre o presente e o passado, eassim, no interior de cada relação construída entre o presente da imagem dada e o passado que cada pessoa carrega dentro de si. Na heterotopia foucaultiana de Kátia Maciel, o corpo, o pensamento e a memória aceleram fruição. A ética em sua produção tem uma crescente consciência de um novo estatuto do corpo. No espaço-outro de "Suspense", experimenta imagens vertiginosas de fora e aquelas que surgem dentro de si mesmo, engolido nas relações e contradições existentes entre a ficção, a memória e o real.

\title{
Conclusão
}

As obras transmidiáticas de André Parente e Kátia Maciel, aqui exemplificadas por "Circuladô" e "Suspense", resultam de uma profunda reflexão dos procedimentos do cinema, do 
vídeo e das novas tecnologias no contexto da arte contemporânea. Através desses componentes tônicos caracterizantes, fomentam a reflexão na recepção. São ambientes expandidos, de imersão, que trazem força ao corpo pois deslocam a percepção do espaço-tempo, quebram a narrativa linear do cinema tradicional e, assim, consentem lacunas para otimizar sentidos e pensamentos no participante durante os rebatimentos com a obra. Trata-se de obras que, desde o gesto de construção até sua reverberação na participação, abolem a autonomia da imagem para fazer nascer um dispositivo processual de interação que reforça e atualiza, alinhado com o pensamento da arte contemporânea, os eventos transmidiáticos de vanguarda que tiveram início nas décadas de 1960 e 1970.

NOTAS

1. Texto original em inglês. Disponível em: < http://randallszott.org/>. Acesso em: 26 abr. 2016

2. "Shelter", do inglês “abrigo".

3. Ironicamente ao repúdio de Hélio Oiticica às instituições de arte, sua obra é hoje reverenciada em espaços oficiais da arte contemporânea, principalmente através de exposições.

4. O apartamento de Smith em Nova York era um duplex e, no segundo andar, ele construiu um labirinto imagético-fantástico.

5. Texto original em inglês.

6. Heterotopia é um conceito elaborado pelo filósofo Michel Foucault para descrever lugares e espaços que funcionam em condições não hegemônicas. Trata-se de espaços de alteridade, que são simultaneamente físicos e mentais, como o momento em que alguém se olha no espelho.

7. Texto original em francês.

8. Também foi exposta em outros formatos e em outros espaços de arte, tais como a Galeria Fayga Ostrower, Funarte Brasília, em 2014.

9. "Isadora” é um software que oferece um ambiente de programação gráfica que possibilita o controle interativo sobre uma mídia digital. Com esse programa, pode-se manipular e interagir com um vídeo em tempo real.

10. Zoetrope é um dispositivo de animação pré-cinema do século XIX que produz a ilusão de movimento, através de uma sequência de desenhos ou fotografias. O termo "Zoetrope" foi composto a partir das palavras de raiz grega zoe, "vida", e tropos, algo como "girando e transformando".

11. Texto retirado do site da Galeria Mamute (http://www.galeriamamute. com.br/\#!giro/cqıa), por ocasião da exposição GIRO (de abril a maio de 2014), sob curadoria de André Parente, cujos artistas participantes foram: André Parente, Caetano Dias, Dirceu Maués, Gisela Motta e Leandro Lima, Jailton Moreira, Katia Maciel, Mariana Manhãs e Sara Ramo.

12. Trecho de entrevista dos pesquisadores deste artigo com Kátia Maciel.

13. Suspense se refere ao gênero cinematográfico e ao corpo suspenso. 
14. Sua segunda mostra ocorreu nas Cavalariças do Parque Lage, no Rio de Janeiro (Curadoria Paula Alzugaray) e reúne as obras "Pista" (2015), "Verso" (2013), "Vulto" (2013) e "Uma árvore" (2009).

15. Trecho de entrevista dos pesquisadores deste artigo.

16. Tradução da pesquisadora. Texto original em francês disponível em: < http://quefaire.paris.fr>. Acesso em: 29 jun. 2014.

17. Trecho de entrevista dos pesquisadores deste artigo.

\section{Referências}

BASBAUM, Ricardo. KM: Devarios. Catálogo Dois (org. André Parente e Kátia Maciel). Caixa Cultural, Brasília: 2014. Disponível em: <http://statici.squarespace.com/ static/5446cccce4bo721294212654/t/54c64358e4bodec48 bcd370o/1422279512331/livro+dois.pdf. >. Acesso em: 26 abr. 2015.

BAUDELAIRE, Charles. Le Peintre de la vie moderne. Dans Le Figaro, 1863.

BOURRIAUD, Nicolas. Formas de vida: a arte moderna e a invenção de si. Tradução Dorothée de Bruchard. São Paulo: Martins Fontes, 2011. (Coleção Todas as Artes)

CARRAPATOSO, Thiago. A arte do cibridismo. Disponível em: <http://www.academia.edu/2553888/A_Arte_do_Cibridismo >. Acesso em: 5 maio 2015.

COSTA, Cacilda Teixeira da. Wesley Duke Lee: um salmão na corrente taciturna. São Paulo: EDUSP, 2005.

DELEUZE, Gilles. L'image-mouvement. Cinéma 1. Paris: Les Éditions de Minuit, 1983. L’image-temps. Cinéma 2. Paris: Les Éditions de Minuit, 1985 .

\& GUATTARI, Félix. Mil platôs: capitalismo e esquizofrenia. v. I. São Paulo: Ed. 34. 2004.

DEWEY, John. Últimos Escritos, 1925-1953. In: BOYDSTON, Jo Ann (Org.). Arte como Experiência. Tradução Vera Ribeiro. São Paulo: Martins Fontes, 2010. 648 p.

LAGNADO, Lizette. A instauração: um conceito entre instalação e performance. In: BASBAUM, Ricardo. Arte contemporânea brasileira. Rio de Janeiro: Rios Ambiciosos, 2001.

MACIEL, Kátia. Transcinemas e a estética da interrupção. In: BRUNO, Fernanda; FATORELLI, Antonio. Limiares da Imagem: Tecnologia e Estética na Cultura Contemporânea. Rio de Janeiro: Mauad Editora, 2006.

MACIUNAS, George. Manifesto on Art - Fluxus Art Amu- 
sement, 1965. Disponível em: <http://randallszott.org/>. Acesso em: 18 maio 2015.

MACHADO, Arlindo. Made in Brasil: três décadas do vídeo brasileiro. São Paulo: Iluminuras: Itaú Cultural, 2007.

MCSHINE, Kynaston. Information Exhibition Research. Disponível em: <www.moma.org/learn/resources/archives>. Acesso em: 9 set. 2012

MELLO, Christiane. Extremidades do Vídeo. São Paulo: Editora Senac, 2008.

MORSE, Margaret. Video installation art: the body, the image, and the space-in-between. In: HALL, Doug; FIFER, Sally Jo (Org.). Illuminating video: an essential guide to video art. New York: Aperture, 1990.

OITICICA, Hélio. Hélio Oiticica. Carta ao Guy Brett, 2 de abril de 1968. Rio de Janeiro: Rioarte, 1996

. Aspiro ao grande labirinto. Rio de Janeiro: Rocco, 1986.

PARENTE, André. A forma cinema: variações e rupturas. In: MACIEL, Kátia (Org.). Transcinemas. Rio de Janeiro: Contra Capa, 2009, p. 23-47.

. Cinema em trânsito: cinema, arte contemporânea e novas mídias. Rio de Janeiro: Azougue Editorial, 2011.

. "Circuladô". Entrevista concedida à Casa de Cultura da América Latina (Brasília/DF). Galeria Fayga Ostrower (Complexo Cultural Funarte Brasília), 2014. Disponível em: $<$ www.casadacultura.unb.b.>. Acesso: 10 jul. 2015.

Programa Hélio Oiticica (PHO) / Itaú Cultural. Disponível em: $<$ http://www.itaucultural.org.br/aplicexternas/enciclopedia/ ho> e Arquivo Hélio Oiticica (AHO) - Catálogo Raisonné disponível em DVD. Textos acessados: $\mathrm{PHO}$ 0316/73, $\mathrm{PHO}$ 0409/72, AHO 253.66 e AHO 1111.71.

RUSH, Michael. Novas Mídias na Arte Contemporânea. Tradução Cássia Maria Nasser. São Paulo: Martins Fontes, 2006.

SANTAELLA, Lúcia. Culturas e artes do pós-humano: da cultura das mídias à cibercultura. São Paulo: Paulus, 2003. p. 162.

VOSTELL, Wolf. The Art of Wolf Vostell. Bélgica: Verbeke Foundation, 14.04.2012 a 29.07.2012. (Catálogo da exposição Dé-coll/age).

YOUNGBLOOD, Gene. Expanded Cinema. New York: Dutton, 1970.

Recebido em: 30/05/15

Aceito em: 06/03/16 


\section{NATASHA MARZLIAK \\ natashamarzliak@hotmail.com}

Bacharel em Artes Visuais (2005), mestra em Cultura Audiovisual e Mídia (2012) e doutoranda em Multimeios e Arte (2014 - andamento) no Departamento de Artes Visuais do Instituto de Artes da Universidade Estadual de Campinas (UNICAMP) com sanduíche no Departamento de Cinema e Audiovisual da Université Panthéon-Sorbonne Paris 1. Artista visual, cineasta e pesquisadora, atua em projetos de video-arte, filme experimental e de vídeo e cineinstalação.

\section{JOSÉ EDUARDO RIBEIRO DE PAIVA \\ eduardopaivacampinas@gmail.com}

Professor do Departamento de Multimeios, Mídia e Comunicação do Instituto de Artes da Universidade Estadual de Campinas (UNICAMP) e professor do programa de Pós-Graduação em Artes Visuais e do programa de Pós- Graduação em Música da mesma instituição. Graduado em Música, mestre em Artes e Doutor em Multimeios, desenvolve, desde os anos 8o, trabalhos sobre as relações entre arte, mídia, tecnologia e produção audiovisual.

\section{MARCELO ANTONIO MILARÉ VERONESE}

besotcc@hotmail.com

Bacharel em Letras (1998), Mestre em Teoria e História Literária (2009) e Doutor em Teoria e História Literária (2011 - 2015) pelo Instituto de Estudos da Linguagem (IEL) da Universidade Estadual de Campinas (UNICAMP). Tem experiência na área de Língua Portuguesa, Redação, Poesia e Literatura, com ênfase em: Poesia Brasileira, Literatura Brasileira, Poesia Italiana, Poesia Inglesa, Poesia Francesa, Beat Generation. 